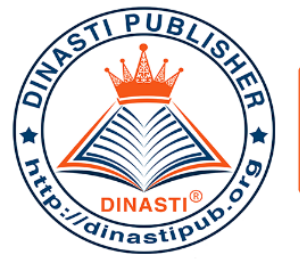

\title{
THE EFFECT OF COMPENSATION, CAREER DEVELOPMENT AND WORK EXPENSES ON TURNOVER INTENTION AT PT SUKSES KELOLA PERSADA
}

\section{Silvia Rahma Dini' ${ }^{1}$, Charles Bohlen Purba ${ }^{2}$}

1) Student Of Magister Management Program, Mercu Buana University, Jakarta, Indonesia,

2) Lecture Of Magister Management Program, Mercu Buana University, Jakarta, Indonesia

\begin{tabular}{|c|c|}
\hline $\begin{array}{l}\text { ARTICLE INFORMATION } \\
\text { Received: } 31 \text { August } 2020 \\
\text { Revised: } 25 \text { September } 2020 \\
\text { Issued: } 9 \text { November } 2020 \\
\text { Corresponding author: Silvia } \\
\text { Rahma Dini } \\
\text { E-mail: } \\
\text { silvrahdin@gmail.com } \\
\text { DOI:10.31933/DIJDBM }\end{array}$ & $\begin{array}{l}\text { Abstract: This study aims to measure the effect of } \\
\text { compensation, career development, and workload on } \\
\text { turnover intention of PT. Successfully Manage Persada } \\
\text { or Trade Mall Mangga Dua Square. This research is } \\
\text { quantitative in nature. The population is all employees } \\
\text { of PT. Success Manage Persada. The sampling } \\
\text { technique was random sampling with a sample of } 114 \\
\text { employees. The research data were analyzed using } \\
\text { multiple linear regression using the SPSS } 25 \text { test tool. } \\
\text { The results of the t-test for compensation and career } \\
\text { development variables partially had a significant } \\
\text { negative effect, and workload partially had a } \\
\text { significant positive effect on turnover intention. The } \\
\text { results of the F-test show that the Sig. ie } 0.000 \text { and less } \\
\text { than 0.05. This indicates that the variables of } \\
\text { Compensation, Career Development, and Workload } \\
\text { together have a significant effect on Turnover Intention } \\
\text { (H4 accepted). The results of the normality test showed } \\
\text { that } 0.96 \text {, which means greater than } 0.05 \text {. This means } \\
\text { that the residual data is normally distributed. } \\
\text { Suggestions for further research are to include other } \\
\text { factors that have a strong influence with Turnover } \\
\text { Intention. } \\
\text { Keywords: Compensation, Career Development, } \\
\text { Workload, Turnover Intention }\end{array}$ \\
\hline
\end{tabular}

\section{INTRODUCTION}

The development of the trade mall business is now being felt very rapidly in Indonesia. Businessmen compete to build magnificent malls in strategic places in order to attract many visitors. Apart from a strategic location, there are many factors that can attract the attention of 
visitors, namely complete facilities, tenant malls that have good quality from local and international brands as well as safety and comfort.

Agung Podomoro Group, through 9 trade mall projects, continues to prove its existence. The nine trade malls are Blok B Tanah Abang, Blok M Square, Seasons City, Thamrin City, Mangga 2 Square, Harco Glodok, Kenari Mas, LTC Glodok, and Plaza Balikpapan. Not only relying on food and beverage tenants, Trade Mall Agung Podomoro Group or TM APG is starting to clean up following the current market rate. One of them is the integration with digital technology which is currently the focus of the company. To continue to grow, a company needs to have superior, creative resources, and be able to find new opportunities that can beat competitors.

Human resources (HR) are very important for carrying out company strategies and achieving company goals. An important element for maximum achievement of company goals is human resources who are competent in their fields and can drive all activities through optimal performance. Quality human resources indirectly provide a picture of the quality that is built from an organization. To get superior human resources, of course, companies must invest in employees by providing training and development.

To improve the performance of company employees, it is necessary to take several ways such as providing adequate compensation, a conducive environment, as well as the education and training needed so that employees can achieve satisfaction and are committed to completing the performance which is the goal of the company, but if this is not carried out by the company it will result bad for the development of each employee in the company, employee satisfaction and employee commitment are getting lower and of course will affect the desire of employees to leave the company (turnover intention).

The exit and entry of employees is a phenomenon that is important for the sustainability of the company. Employee turnover sometimes has a positive and negative impact on the sustainability of the company. Employee turnover is mostly not good for the company in terms of time, cost, opportunities and opportunities. Tet and Mayer in Khaidir (2016) argue that intention to leave or turnover intention is the intention or desire of employees to leave the company consciously.

The desire to change employees on the grounds of wanting to get a better job in terms of compensation, work environment, training and development, workload that is too heavy, doesn't fit the organizational culture, and other reasons is called turnover intention. Handoko in Khaidir (2016) if the compensation provided is not competitive, good employees will leave the company.

PT. Sukses Kelola Persada was founded on June 18, 2005 and is engaged in the management of the two square mango trade mall owned by the Agung Podomoro Group (APG). Mall Mangga Dua Square offers a "One Stop Shopping" trade mall concept that provides all the needs of its visitors. PT. Sukses Kelola Persada has serious problems related to the turnover of employees, along with the turnover data of PT Sukses Kelola Persada.

In 2017 there were 49 employees of PT Sukses Kelola Persada who resigned and entered work with a percentage of $14.02 \%$. In 2018 there were 53 employees who resigned, 14 employees entered with a turnover rate of $17.07 \%$, while in 2019 there was a decrease in the number of employee resignations by 39 employees, but only 3 employees entered with a turnover rate of $15.18 \%$. It is suspected that there is a turnover intention problem in PT Sukses Kelola Persada. The number of employees who left 2017-2019 was not proportional to the number of employees who entered, meaning that many employees carried out more work tasks because they replaced the duties of resigned employees. 


\section{LITERATURE REVIEW \\ Compensation}

Compensation and remuneration are very important for employees because the amount of compensation reflects a measure of their performance. According to Rivai \& Sagala (2011: 741), compensation is something that employees receive as a substitute for their service contribution to the company. The provision of compensation is one of the implementation of the HRM function which deals with all types of giving individual awards as an exchange in carrying out organizational tasks. Compensation provided in the form of money or other, which can be in the form of salaries, wages, bonuses, incentives and holiday allowances, food allowances, leave money, and others.

Meanwhile, according to Mondy (2008: 5), compensation is the total amount of compensation received by employees in lieu of the services they have provided. Total compensation is shown in direct financial compensation as well as indirect compensation. In addition, in the latest survey there is a reward / compensation that is not in financial form, which is called non-financial compensation. Zainal et.al (2018: 541) said that if a company provides low compensation and remuneration that is deemed inappropriate for employees, then there will be difficulties in obtaining employees and employing employees who are deemed capable or can affect employee morale. However, if the compensation and remuneration provided by the company is deemed appropriate and fair, then the employees will tend to devote their utmost to the company.

\section{Career Development}

Career Development programs are becoming an important and vital activity in business and industry today. Career development is an HR strategy to help employees find and develop their abilities so that they can be optimal in achieving performance. Career development can be used to increase productivity, improve employee attitudes towards work, and develop higher employee satisfaction. Career development is the result of the interaction between individual careers and the organizational career management process. Zainal et.al (2018: 207) states that the principle goal of career development programs is to help employees analyze in terms of their abilities to be better able to match many of their needs for growth and development goals with company needs. Commitment to career development can delay the obsolescence of human resources that are burdensome for the company.

According to Henry Simamora (2004: 412) said that career development includes career management and career planning (career planning). Understanding career development in an organization requires an examination of two processes, namely how each person plans and implements career goals (career planning) and how the organization designs and implements career development programs. Career planning is a process through which individual employees identify and take steps to achieve their career goals. Career planning involves identifying career-related goals and drawing up plans to achieve those goals. Realistic career planning forces individuals to see the opportunities that exist in relation to their abilities. Career management is a process carried out by an organization to select, assess, assign and develop its employees to provide a competent pool of people to meet future needs.

\section{Workload}

Workload is one aspect that must be considered by companies or organizations because it involves comfort at work. A number of activities that must be done by employees are called workloads. Completion of tasks carried out by employees must be well scheduled 
so that the completion of tasks is on target. According to Meshkati in Tarwaka (2015), workload can be defined as a difference between the capacity or ability of workers and the job demands that must be faced. Considering that human work is mental and physical, each has a different level of burden. The level of loading that is too high allows excessive energy use and over stress, on the other hand, the intensity of the loading that is too low allows a feeling of boredom and boredom or understress. Therefore it is necessary to strive for an optimum loading intensity level that is between the two extreme limits and of course it differs from one individual to another.

According to Sunyoto (2012: 64) says that too much workload can cause tension in a person, causing stress. This can be due to the level of expertise demanded is too high, the volume of work may be too much and so on. It can be concluded from the theory above that the workload can be defined as to how far the employee's capacity is needed to complete a given task, which can be indicated from the amount of work that must be done, the time / time limit the employee has in completing his task, and the employee's subjective view. himself regarding the work assigned to him. According to Hart \& Stavelan in Tarwaka (2011: 131) work measurement can be done through subjective measurement of mental work (Subjective Method), one of which uses the Subjective Workload Assessment technique (SWAT) in the SWAT method, human work performance consists of three dimensions. the size of the workload associated with performance, namely:

1. Time load, shows the amount of time available in planning, implementing and monitoring tasks or work.

2. Mental effort load, the amount of mental effort in carrying out a job.

3. Psychological stress load, shows the level of work risk, confusion, and frustration.

\section{Turnover Intention}

Turnover is a person's desire to leave the job he is currently doing. One of the wishes to leave the company is to get a better job from a financial perspective, career development, work environment and so on. High employee turnover rates will cause potential costs, both recruitment costs, training costs, and decreased company performance due to employee vacancies. Turnover Intention can cause disruption in operations, disrupt work teams and unit performance. Robbins and Judge (2017: 220) in Ramadhan 2018 explain that turnover can occur voluntarily (voluntary turnover) or involuntary (involuntary turnover). Voluntary turnover or quit is an employee's decision to leave the organization voluntarily due to factors of how attractive the current job is, and the availability of other job alternatives. Conversely, involuntary turnover or dismissal describes the employer's decision to terminate the work relationship and is uncontrollable for employees who experience it.

According to Harnoto in Ramadhan (2018), states: "turnover intention is the level or intensity of the desire to leave the company, there are many reasons that cause this turnover intention and among them is the desire to get a better job." This opinion is also relatively the same as the opinion previously expressed, that turnover intentions are basically the desire to leave (exit) from the company. Meanwhile, according to Mobley (1986) states that the (intense) desire to leave the organization is a dominant predictor that is positive for turnover. The desire to move refers to the results of individual evaluations regarding the continuation of their relationship with the organization and has not shown definite action to leave the organization. The dimensions of turnover intention according to Mobley in Farida (2018: 198) include:

1. Thinking of quitting, is the thought of an employee to leave a company and the thought that he may not stay with the company. 
2. Intent to search, is the attitude of an employee to look for alternatives to other companies.

3. Intent to quit, is the attitude of an employee that shows indications of leaving, such as minimizing work effort, and canceling important work.

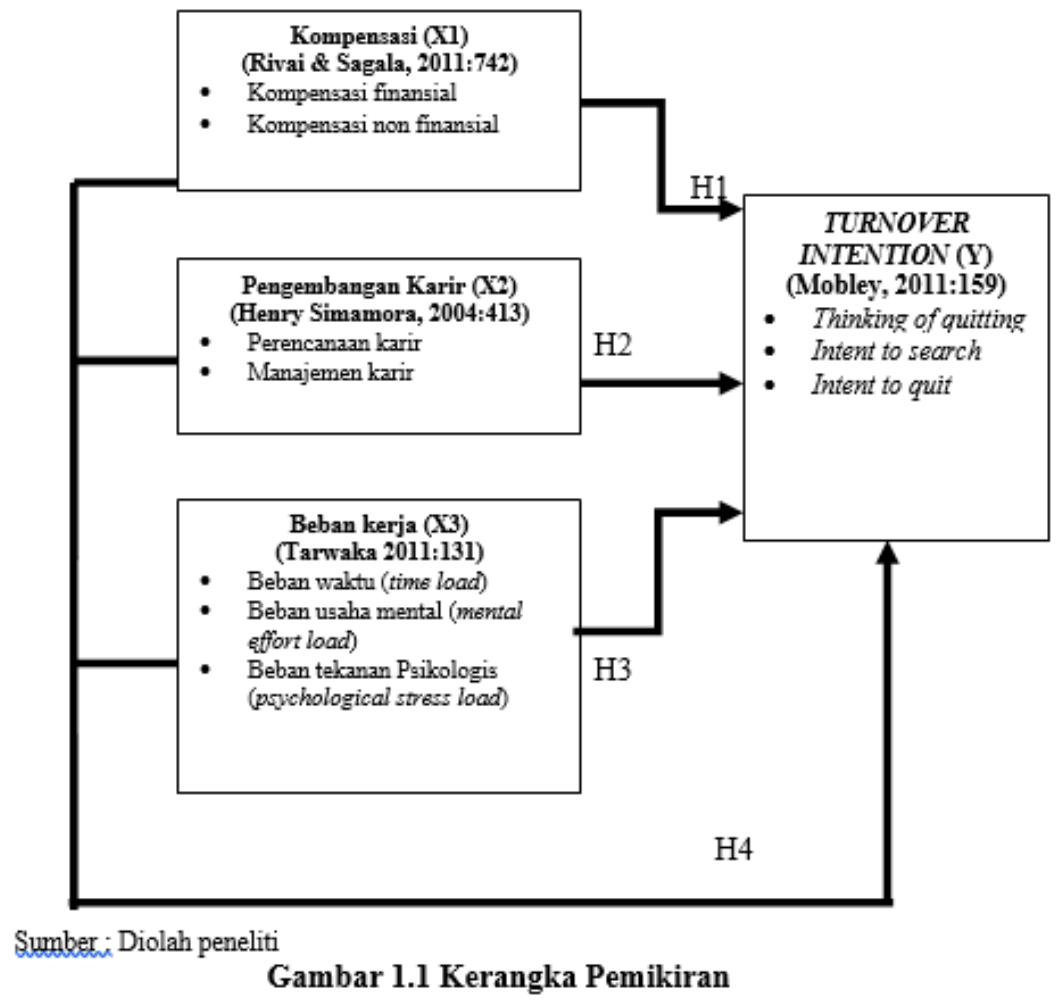

\section{Research Hypothesis:}

H1: Compensation has a significant negative effect on turnover Are you interested in PT Sukses Kelola Persada?

H2: Career development has a significant negative effect on turnover intention at PT Sukses Kelola Persada?

H3: Workload has a significant positive effect on turnover Are you interested in PT Sukses Kelola Persada?

H4: Career development, Workload, and Compensation Has a significant effect on turnover intention at PT Sukses Kelola Persada?

\section{RESEARCH METHODS}

This study is a study that aims to analyze the effect of compensation, career development, and workload on turnover intention. The population in this study were employees of PT Sukses Kelola Persada. The sampling technique in this study was the random sampling technique, namely as many as 114 respondents. This study used a survey method to collect data, namely data collection and analysis techniques in the form of opinions from the subjects studied through questionnaires, interviews, and observations. The data analysis method used in this study was the Statistical Package for the Social Sciences (SPSS) software version 25 .

The research design used an exploratory survey method with a causal approach. This causal approach is a method for seeing the relationship between variables to the object under study is cause and effect, so that in his research there are independent variables and there are 
dependent variables in them (Sakaran \& Bougie 2017: 112). The scale used in this study is the Likert scale. The Likert scale is used as a measure of attitudes, opinions and perceptions of people or groups of people about social phenomena. In this scale, the selected number is directed with a minimum value of at least 1 and a maximum height of 5 .

\section{FINDINGS AND DISCUSSION}

\section{Validity Test}

The results of the validity test obtained 8 items of compensation variables, 7 items of career development variables, 14 items of workload variables, and 8 items of turnover intention variables.

\section{Reliability Test}

The reliability test was conducted to determine the extent of the consistency of the research instrument or to what extent the research instrument could be consistent if it was used repeatedly in different periods of time.

Compensation Alpha value of Crombach is 0.919, Career Development is 0.912, Workload is 0.966 , and Turnover Intention is 0.934 . It can be concluded that all research instruments from all variables are declared reliable because the Cronbach Alpha value is> 0.6 so that the above variables can be used in this study.

\section{Normality Test}

The normality test is carried out to determine whether the sample from the study population is normally distributed or not. The normality test is carried out after passing the stages of the validity and reliability test.

Criteria for the Kolmogorov-Smirnov One-Sample Test, namely based on criteria. Sig $<0.05$, then the residual data is not normally distributed. If asyimp. Sig $>0.05$, then the residual data is normally distributed. The results show a value of 0.96 which means that it is greater than 0.05 . This means that the residual data above are normally distributed.

\section{Multicoleniarity Test}

The results of this test are seen based on the magnitude of the tolerance value and VIF (variance inflated factor).

The amount of tolerance value in each variable is greater than 0.1 and the magnitude of the VIF value in each variable is less than 10. It can be concluded that the regression model in this study is free from multicollinearity between independent variables.

\section{Heteroscedasticity Test}

The heteroscedasticity test in this study used the Glejser method by performing a regression analysis of all independent variables $(\mathrm{X} 1, \mathrm{X} 2, \mathrm{X} 3)$ on the absolute residual value.

The sig value of compensation is 0.645 , career development is 0.127 , and workload is 0.611. It is known that all the variables have the value of Sig. on the independent variable is greater than 0.05 . This means that all independent variables do not have heteroscedasticity symptoms in the residual data or can be said to be homoscedasticity.

\section{Results of Multiple Linear Regression Analysis}

Linear regression is needed to measure the magnitude of the relationship that occurs between two or more variables. Linear regression is also needed to determine the direction of the relationship between the independent variables and the related variables, this direction is 
positive or negative. Regression analysis in this study is used to analyze whether there is an influence between the independent variables, namely Compensation (X1), Career Development (X2) and Workload (X3) on the dependent variable, namely Turnover Intention (Y), and independent variables on the dependent variable simultaneously.

Table 4.1 Results of Multiple Linear Regression Analysis

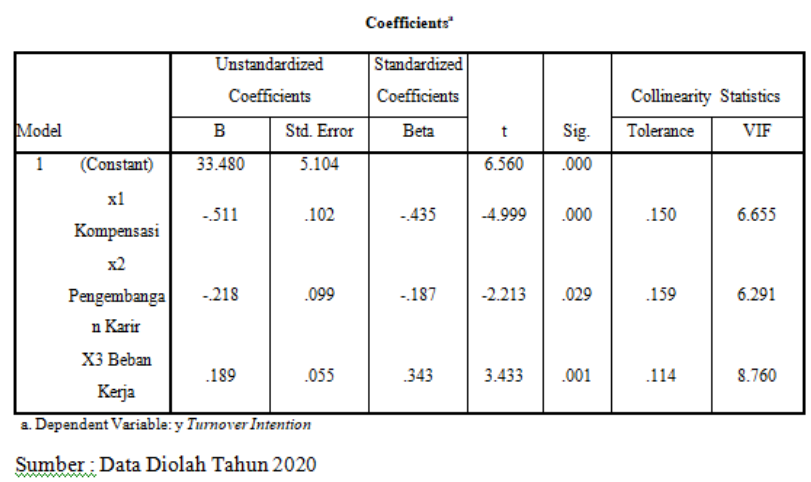

Based on Table 4.1. in the Unstandardized Coefficients B column shows a constant value $(\alpha)$ of 33,480 and in the next row the coefficient of the independent variable (b) is Compensation of -0.511 , Career Development of -0.218 and Workload of 0.189 , the regression equation can be arranged as follows:

$\mathrm{Y}=\alpha+\beta 1 \mathrm{X} 1+\beta 2 \mathrm{X} 2+\beta 3 \mathrm{X} 3+\mathrm{e}$

$\mathrm{Y}=33,480+(-0,511) \mathrm{X} 1+(-0,218) \mathrm{X} 2+0.189 \mathrm{X} 3+\mathrm{e}$

Based on the regression equation previously described, it can be explained as follows:

1. This constant $(\alpha)$ indicates that if all independent variables have a zero value $(0)$ then the value of the dependent variable (Beta) is 33,480 .

2. A constant value of 33,480 indicates that if the variables of Compensation (X1), Career Development (X2), and Workload (X3) are constant, then Turnover Intention (Y) is 33,480 .

3. Compensation (X1) for Turnover Intention (Y). The regression coefficient for the Compensation variable (X1) is -0.511 and is negative. This indicates that Compensation has a relationship that is not in the same direction as Turnover Intention. This also implies that for each one-unit reduction in the value of compensation, the value of the Turnover Intention (Y) variable will decrease by -0.511 with the assumption that the value of the Career Development and Workload variables in the regression model is constant. This means that if the compensation is low, then turnover intention will increase.

4. Career Development (X2) towards Turnover Intention (Y). The career development variable regression coefficient (X2) is -0.218 and is negative. This shows that Career Development has a unidirectional relationship with Turnover Intention. This also implies that every one-unit decrease in the value of Career Development, the value of the Turnover Intention (Y) variable will decrease by -0.218 with the assumption that the value of the Compensation and Workload variables in the regression model is constant. 
That is, if career development is good and not as expected by employees, the turnover intention will increase.

5. Workload (X3) on Turnover Intention (Y). The regression coefficient of the Workload variable (X3) is 0.189 and is positive. This indicates that Workload has a direct relationship with Turnover Intention. This also implies that every one-unit decrease in the value of Workload, the value of the Turnover Intention (Y) variable will decrease by 0.189 assuming that the value of the Compensation and Career Development variable in the regression model is fixed. This means that if the workload increases, then turnover intention will also increase.

\section{Test of the coefficient of determination}

The coefficient of determination test is carried out to determine how much the contribution or contribution of the independent variable to the dependent variable.

It is known that the $\mathrm{R} 2$ value is 0.875 , which means that the compensation, career development and workload variables contribute $87.5 \%$ to the Turnover Intention variable, while the remaining $12.5 \%$ can be explained by other variables.

\section{F test}

The $\mathrm{F}$ test is performed to determine whether all the independent variables in the regression model have a joint influence on the dependent variable.

Table 4.2 F Test Results

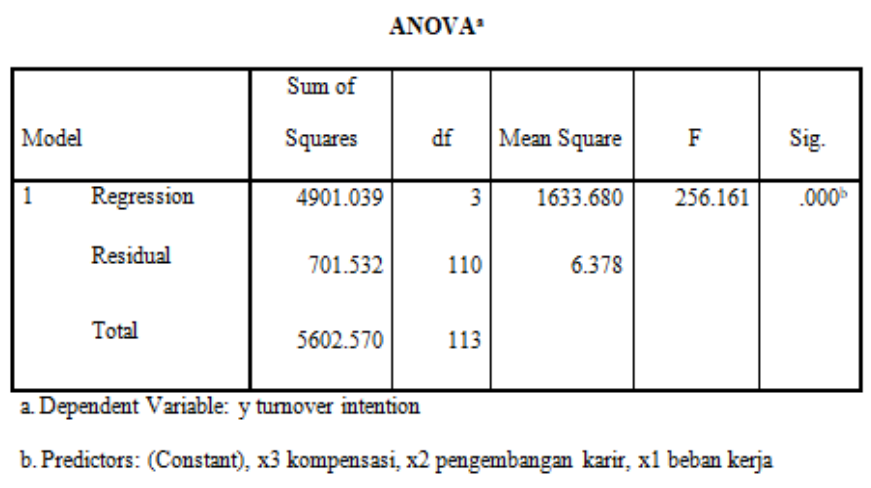

Source : Data Processed on 2020

Based on Table 4.2, it is known that the results of the Sig. namely 0.000 and less than 0.05. This indicates that the variables of Compensation, Career Development, and Workload together have a significant effect on Turnover Intention (H4 accepted).

\section{T test}

The $t$ test is conducted to determine how much influence each independent variable has on the dependent variable. This t test also aims to estimate the extent of the contribution of changes that occur in each independent variable to the size of the dependent variable. The criteria for making a decision from the $t$ test are as follows: 
If the value of $t$ count $>t$ table and the value of sig. $<0.05$ then Ho is accepted

If the value of $t$ count $<\mathrm{t}$ table and the value of sig. $>0.05$ then Ha is rejected

Table $4.3 \mathrm{t}$ test results

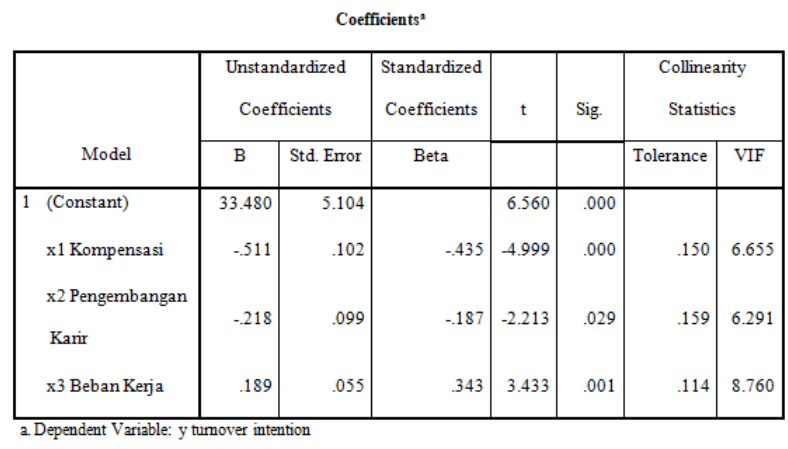

Sumber: Data Diolah Tahun 2020

Based on Table 4.3, the following conclusions can be drawn:

1. H1: Compensation has a value of $t$ count of 4.999> 0.182 ( $\mathrm{t}$ table) and has a value of Sig. 0.000 is less than 0.05 . This means that Compensation partially has a significant negative effect on Turnover Intention.

2. H2: Career Development variable has a t value of 2,213>0.182 (t table) and has a Sig. 0.029 is greater than 0.05 . This means that Career Development partially has a significant negative effect on Turnover Intention.

3. H3: Workload variable has a t-count value of 3,433>0.182 (t table) and has a Sig. 0.001 is less than 0.05 . This means that Workload has a significant positive effect on Turnover Intention.

4. The highest value on standardized coefficients beta is in the compensation variable which is equal to 0.435 . This shows that the variable that has the greatest influence on Turnover Intention is compensation

\section{Dimensional Correlation Test}

Correlation test between dimensions is tested to determine the magnitude of the relationship between each dimension of all independent variables with each dimension on the dependent variable. The results of the inter-dimensional correlation test use the Pearson's correlation two-tailed method and will be detailed in the following table: 
Table 4.4 Inter-Dimensional Correlation Matrix

\begin{tabular}{|c|c|c|c|c|}
\hline Variabel & Dimensi & $\begin{array}{l}\text { Thinking of } \\
\text { Quitting }\end{array}$ & $\begin{array}{l}\text { Intent To } \\
\text { Search }\end{array}$ & $\begin{array}{l}\text { Intent } \\
\text { To } \\
\text { Quit }\end{array}$ \\
\hline \multirow[t]{2}{*}{ Kompensasi } & $\begin{array}{l}\text { Kompensasi } \\
\text { Finansial Langsung }\end{array}$ & -0.855 & $-0,791$ & $-0,873$ \\
\hline & $\begin{array}{l}\text { Kompensasi } \\
\text { Finansial Tidak } \\
\text { Langsung }\end{array}$ & $-0,765$ & $-0,719$ & $-0,777$ \\
\hline \multirow{2}{*}{$\begin{array}{l}\text { Pengembang } \\
\text { an Karir }\end{array}$} & Perencanaan Karir & $-0,798$ & $-0,745$ & $-0,856$ \\
\hline & Manajemen Karir & $-0,894$ & $-0,734$ & $-0,788$ \\
\hline \multirow[t]{2}{*}{ Beban Kerja } & $\begin{array}{l}\text { Beban Waktu } \\
\text { Beban Usaha Mental }\end{array}$ & $\begin{array}{l}0,842 \\
0,864\end{array}$ & $\begin{array}{l}0,776 \\
0,751\end{array}$ & $\begin{array}{l}0,833 \\
0,867\end{array}$ \\
\hline & $\begin{array}{l}\text { Beban Tekanan } \\
\text { Psikologis }\end{array}$ & 0,802 & 0,782 & 0,824 \\
\hline
\end{tabular}

Sumber : Data Diolah Tahun 2020

The correlation can be concluded that:

1. In the compensation variable, the dimension that has a strong relationship is the dimension of direct financial compensation (X1.1) on turnover intention in the thinking of quitting dimension (Y1.1), because it has a coefficient value of 0.855 . Meanwhile, a low value is found in the indirect financial compensation dimension (X1.2) on the turnover intention dimension of intent to search (Y1), because it has a coefficient of 0.719 .

2. In the career development variable, the dimension with the strongest relationship is the dimension of career management (X2.2.) On turnover intention in the dimension of thinking of quitting (Y1.2), because it has a coefficient value of 0.894. Meanwhile, the low level of relationship is in career management with the dimension of career management (X2.2) on turnover intention in the intent to search dimension (Y1.2), because it has a coefficient value of 0.734 .

3. In the workload variable, the dimension that has a high relationship is the mental business load dimension (X3.2) on turnover intention in the intent to quit dimension (Y1.3), because it has a coefficient value of 0.867. Meanwhile, a low value is found in the mental operating load dimension of 0.751 (X3.2) on turnover intention in the intent to search dimension (Y3.2), because it has a coefficient value of 0.751 .

\section{CONCLUSION AND SUGGESTION \\ Conclusion:}

1. Compensation has a significant negative effect on Turnover Intention. This means that the compensation given by PT. Sukses Kelola Persada is still low, so it automatically results in a high turnover intention. This is because the compensation received by the work tasks performed by employees is not comparable. This is what triggers employees to be dissatisfied with compensation. The company should provide compensation in accordance with the performance and workload of the task. 
2. Career Development has a significant negative effect on Turnover Intention. This means that the career development of PT Sukses Keloal Persada is low or not going well due to the lack of opportunities provided in terms of career paths and ineffective training provided to employees, which causes the turnover intention to increase.

3. Workload has a significant positive effect on Turnover Intention. This means that the workload carried out by employees increases because employees who are still working at PT Sukses Kelola Persada are charged with job duties of employees who have resigned without an increase in compensation, which causes the turnover intention rate to increase.

4. Compensation, Career Development, and Workload simultaneously have a significant effect on Turnover Intention. This means that in this study there are problems with turnover intention caused by problems with compensation, career development and workload.

\section{Suggestion :}

1. The leadership and HCD of PT. Success of Kelola Persada should simultaneously increase compensation, career development, and reduce the workload of employees in order to reduce turnover intention. In this case compensation and career development need to be increased and prioritized, and the workload needs to be reduced so that the turnover intention is not high.

2. PT. Success Kelola Persada must pay attention to the training provided to be more effective in improving the performance of each employee and division. After each training completion, the company should conduct a test on employees who take part in the training, so that the company knows how effective it is and how much knowledge absorption is captured by employees.

3. Manage compensation and allowances in kind. HCD PT. Success Kelola Persada must explore and update data regarding the regulations and the amount of salary to be paid from each industry and provide allowances to employees if needed, as well as bonuses that are clearly organized according to performance which can be seen from the KPI, length of work, and assessments. other.

4. HCD establishes a clear and transparent compensation system. Someone who works heavier and more is very natural if he gets more results than other employees who work normally. The compensation factor is one of the energies of employees in shaping work ethos and morale.

5. Increase employee engagement by increasing social interaction between employees and employees as well as employees and superiors, besides that employees must be rewarded.

6. Before recruiting, HCD must read the potential and placement of prospective employees by analyzing their talents, passions and skills. Differences in job plotting and interests and potential of employees will cause these employees to be unable to 
develop and experience career stagnation. This also happened not only because of the company's fault, but also the failure of employees to adapt.

7. The HCD of PT Sukses Kelola Persada describes the challenges to be faced as well as the career paths. Employees want to know where their careers are headed. Periodic reviews or half a year will maximize employees to find out their career paths. HCD should encourage employees to come to HCD by asking about their career paths and future hopes at PT. Manage Success. Therefore, HCD needs to create a career path for each employee.

8. The workload of the employees' duties is increasing due to replacing the work tasks of employees who are resigned, but not accompanied by additional compensation in accordance with the work tasks given. The HCD should take into account the compensation given based on the workload.

9. Companies must establish employer branding by providing a special identity to employees so that employees feel comfortable and feel they are being treated differently than other companies.

\section{REFERENCE}

Ayodogdu.S and Asikgil.B 2011. 'An Empirical Study of the Relationship Among Job Satisfaction, Organizational Commitment and Turnover Intention', International Review of Management and Marketing Vol. 1, No. 3, pp.43-53.

Azeez,R.O. et.al 2016 oktober, 'Job Satisfaction, Turnover Intention And Organizational Commitment' Lagos state University, Vol. 8 Issue - 2.

Charles.B.P and Dafit.F.B 2019, The Influence Of Leadership, Compensation, and Workload On Iurnover Intention at PT Karya Utama Perdana

Direktorat Pascasarjana 2019, Panduan Penyusunan Tesis \& Artikel Ilmiah Magister, Edisi 01

Farida Elmi 2019, Telisik Manajemen Sumber Daya Manusia, Mitra Wacana Media

Ferdinand, Agusty 2014, Metode penelitian manajemen, penerbit badan penerbit universitas diponegoro.

Firdaus, Ahmad 2017 'Faktor-Faktor Yang Mempengaruhi Turnover Intention (Studi Pada Karyawan Perusahaan Jasa Multi Finance Di Kota Jambi)' Jurnal of Economics and Business Vol.1 No.1.

Henry Simamora 2010, Manajemen Sumber Daya Manusa, Edisi III. Penerbit STIE YKPN.

Khaidir, Muhammad \& Sugiati, Tinik 2016, 'Pengaruh stres kerja, kompensasi dan kepuasan kerja terhadap turnover intention studi pada karyawan kontrak pt. Gagah satria manunggal Banjarmasin', Jurnal Wawasan Manajemen, Vol. 4, Nomor 3. 
Mobley.W.H et.al 1978, 'An Evaluation of Precursors of Hospital Employee Turnover' University of South Carolina. Journal of Applied Psychology. Vol. 63, No. 4, 408-414.

Mondy.R.W 2008, Manajemen sumber daya manusia edisi kesepuluh jilid 1. Penerbit erlangga.

Mondy.R.W 2008, Manajemen sumber daya manusia edisi kesepuluh jilid 2. Penerbit erlangga.

Ramadhan, M.S 2018 'Pengaruh Kompensasi, Motivasi Ekstrinsik, Dan Stres Kerja Terhadap Turnover Intention Karyawan Pt. Aero Systems Indonesia’ Repository mercu buana.

Rivai Veithzal dan Sagala.E.J 2011, Manajemen sumber daya manusia untuk perusahaan dari teori ke praktik, Penerbit PT Rajagrafindo Persada.

Zainal.V.R dkk 2018, Manajemen Sumber Daya Manusia Untuk Perusahaan Dari Teori Ke Praktik. Edisi ketiga. 